Patrycja Żychoń, Michat Piwowarczyk

Uniwersytet Ekonomiczny w Katowicach

patrycja.zychon@edu.uekat.pl,michal.piwowarczyk@edu.uekat.pl

\title{
Aktywność wybranych obiektów szlaku zabytków techniki w mediach społecznościowych w czasie pandemii COVID-19
}

\section{Streszczenie}

Celem pracy jest zidentyfikowanie różnic w aktywności obiektów Szlaku Zabytków Techniki w mediach społecznościowych w czasie pandemii. Analizie poddano media społecznościowe wybranych obiektów ze szlaku, zgrupowane według 3 kategorii: browar, kopalnia oraz muzeum. Analiza wykazała, że obiekty ze sobą współpracowały, przeprowadzały dużo akcji promujących swoje ekspozycje oraz wychodziły $z$ aktywizującymi inicjatywami. Podstawę badań stanowiła krytyczna analiza literatury przedmiotu oraz studium przypadku - Szlaku Zabytków Techniki.

\section{Wprowadzenie}

Pandemia COVID-19, która zaczęła się na przełomie lat 2019 i 2020, wywołuje negatywne konsekwencje dla wielu branż. W wyniku wprowadzanych obostrzeń m.in. placówki kulturalne i turystyczne zostają zamknięte, co skutkuje ograniczeniem ich działalności, w niektórych okresach w zasadzie tylko do sfery wirtualnej. Narzędzia online, w tym media społecznościowe, stają się głównym miejscem, w którym odbiorca ma możliwość poznania walorów kulturowych, a wzbudzone w ten sposób zainteresowanie może przełożyć się na odwiedzenie danej atrakcji, gdy będzie to już możliwe.

Celem pracy jest zidentyfikowanie różnic w aktywności zarządcy Szlaku Zabytków Techniki i wybranych obiektów znajdujących się na nim w mediach 
społecznościowych $\mathrm{w}$ okresie przymusowego zamknięcia obiektów, spowodowanego pandemią COVID-19 w roku 2020. Autorzy założyli, że taka aktywność może w przyszłości przełożyć się na zwiększony ruch turystyczny, po zniesieniu obostrzeń. Przynależność do sieciowego produktu turystycznego, jakim jest szlak, daje w tych okolicznościach pewne szanse wynikające z możliwości współpracy i realizacji wspólnych przedsięwzięć promocyjnych. Jednocześnie region, w którym znajduje się szlak - województwo śląskie - szczególnie w pierwszej połowie 2020 r. zmagał się z negatywnym wizerunkiem wynikającym z dużej liczby zakażeń w kopalniach, które mogły wpływać negatywnie na postrzeganie kopalń udostępnionych do zwiedzania turystom. A takie są częścią Szlaku Zabytków Techniki.

Autorzy scharakteryzowali działania promocyjne podjęte przez zarządcę szlaku w obliczu pandemii, jak również przeanalizowali działania wybranych obiektów według trzech kategorii: browar, kopalnia, muzeum. Badania przeprowadzono w oparciu o aktywność tych obiektów na Facebooku oraz kwerendę literatury i stron internetowych.

\section{Istota Szlaku Zabytków Techniki w dobie pandemii COVID-19}

Produkt turystyczny - szlak kulturowy - obejmuje zestawienie różnorodnych atrakcji kulturowych oraz powiązanych z nimi usług i innych produktów turystycznych $w$ celu korzystania $z$ nich podczas pobytu turysty na szlaku. Do jego cech należą: określona przestrzeń z wyznaczonymi obiektami, złożoność produktów, multiwytwarzalność, która oznacza wiele podmiotów biorących udział w procesie świadczenia usług, oraz synergiczność (Stasiak, 2006).

$\mathrm{Z}$ przedstawionych cech wynika, że produkt turystyczny - szlak - może być także produktem sieciowym. Produkt sieciowy skupia w sobie zarówno elementy materialne, jak i niematerialne, należące do sieci podmiotów, których głównym celem jest odpowiedź na wiele zróżnicowanych potrzeb turystów, charakteryzuje się pewną nadrzędną ideą (marka) oraz danym przedstawicielem tej sieci (Maciąg, 2015).

Sieciowość produktu turystycznego daje wiele wymiernych korzyści. Należą do nich m.in.: elastyczniejsze dopasowanie się do zmieniających się warunków, promocja całego produktu sieciowego oraz poszczególnych obiektów, wzajemna pomoc i współpraca (Balińska, 2017).

Przykładem takiego produktu jest znajdujący się w województwie śląskim Szlak Zabytków Techniki (SZT). Jest to szlak samochodowy, obejmujący 41 obiektów. To industrialna trasa pozwalająca na poznanie przemysłu obejmującego m.in.: górnictwo, kolejnictwo czy hutnictwo. Szlak zawiera m.in.: różnego rodzaju muzea, kopalnie, osiedla, wieże, co świadczy o jego dużej różnorodności. Obiekty można zwiedzać wewnątrz lub tylko z zewnątrz, jak np. osiedla. Gospodarzem szlaku jest Muzeum Górnictwa Węglowego w Zabrzu. SZT posiada 
unikatowe zabytki industrialne, które należą do Gwiazd Techniki. Zostały one wyróżnione ze względu na prezentowane walory kulturowe oraz kompleksową ofertę turystyczną (www.zabytkitechniki.pl).

W Polsce od 12 marca zaczął obowiązywać stan zagrożenia epidemiologicznego. W krótkim czasie nastąpiło zamrożenie gospodarki (tzw. lockdown), w tym również placówek oświatowych i turystycznych. Edukacja i inne sfery życia zaczęły funkcjonować przy wykorzystaniu narzędzi online (www.wiadomosci.onet.pl).

W tym momencie można wyrazić opinię, że o ile przy pierwszym zamknięciu zarządcy obiektów mogli być zaskoczeni nagłą sytuacją, to za drugim razem powinni się lepiej przygotować i można było oczekiwać większej aktywności w mediach społecznościowych.

Epidemia COVID-19 przyniosła negatywne konsekwencje także dla województwa śląskiego, w którym znajduje się analizowany SZT. W województwie tym od maja do sierpnia odnotowywano jedne $z$ najwyższych wartości zachorowań na tle kraju. Głównymi ogniskami wirusa stały się śląskie kopalnie. Ze względu na występowanie ognisk wirusa w kopalniach, obiekty SZT znalazły się w niekorzystnej sytuacji. Na SZT znajdują się nieczynne kopanie, które obecnie pełnią rolę muzeów. Ze względu na wysoki przyrost zachorowań i występowanie ognisk właśnie w kopalniach wizerunek tych obiektów uległ pogorszeniu, co przełożyło się na zmniejszenie frekwencji pomiędzy dwoma okresami zamknięcia (www.portal.abczdrowie.pl).

W związku z tym odpowiednia komunikacja marketingowa była szczególnie ważna. Komunikacja marketingowa, w tym promocja obiektów kulturalnych, polega przede wszystkim na dialogu z otoczeniem. Do jej celów należą: informowanie turystów o atrakcjach kulturowych i ich walorach, zachęcanie do skorzystania $z$ tych atrakcji oraz budowanie więzi z miejscem (Kasperska, 2013).

Promocja obiektów kulturalnych i turystycznych w mediach społecznościowych $\mathrm{w}$ dobie pandemii nie została jeszcze wyczerpująco przeanalizowana $\mathrm{w}$ literaturze. Jedna z pierwszych publikacji wykazała, że: obiekty kulturalne mogą organizować wystawy wirtualne, które poprzedzają promujące posty, publikować filmiki przedstawiające zgromadzone zbiory, organizować konferencje i różnego rodzaju spotkania online (rodzaj public relations), podejmować działania aktywizujące i budujące wizerunek obiektu w mediach, np. urządzać konkursy online. Łącznikiem tych wymienionych wyżej przykładów jest zmobilizowanie odbiorcy do odwiedzenia obiektu po zniesieniu restrykcji. Ponadto obiekty w celu podtrzymania komunikacji marketingowej częściej powinny zamieszczać posty (Kłusek, 2020).

\section{Działania podjęte przez zarządcę szlaku}

Zarządca przeprowadzał różnego rodzaju działania, które były odpowiedzią na zaistniałą sytuację pandemiczną oraz spadek frekwencji w obiektach kopalnianych $\mathrm{w}$ roku 2020. W okresie zamknięcia, czyli wtedy kiedy turysta nie mógł fizycznie zwiedzać obiektu, zarządca organizował różnego rodzaju wydarzenia 
online, natomiast $\mathrm{w}$ okresie otwarcia starał się zachęcić do fizycznego odwiedzenia szlaku poprzez różnego rodzaju wydarzenia organizowane na szlaku. Do głównych działań podjętych przez zarządcę można zaliczyć następujące przedsięwzięcia: „Wybieram Śląskie”, konkurs fotograficzny „Rozumiem Sląskie”, kampanię „Technika. To Was zaskoczy” oraz „Industriadę”.

Kampania „Wybieram Śląskie”, przeprowadzona w lipcu, polegała na zachęcaniu przez znane osoby do odpoczynku w województwie śląskim, pełnym różnych możliwości turystycznych, bogatej kultury i przyrody. Zarządca SZT był partnerem kampanii (www.zabytkitechniki.pl).

Konkurs fotograficzny „Rozumiem Śląskie”, który trwał do końca 2020 r., polegał na umieszczaniu zdjęć na Instagramie związanych z własną interpretacją obiektów szlaku. Miały one wykazać autorskie podejście do walorów regionu poprzez prezentacje fotografii poszczególnych obiektów (www.zabytkitechniki.pl).

Kolejna kampania „Technika. To Was zaskoczy” zaprasza do eksplorowania mniej znanych miejsc SZT. Polega ona na publikowaniu na profilu szlaku na Facebooku oraz na YouTube filmów przedstawiających ciekawostki na temat obiektów. Ambasadorem kampanii jest Tomasz Rożek z kanału na YouTube „Nauka. To Lubię" (www.zabytkitechniki.pl).

„Industriada” to święto szlaku. Corocznej imprezie towarzyszy wiele wydarzeń organizowanych w obiektach. Pierwotnie impreza miała się odbyć w czerwcu, jednakże ze względu na sytuację epidemiologiczną święto zostało przeniesione na 26 września. Turyści z całego kraju w określonym reżimie sanitarnym mogli uczestniczyć $\mathrm{w}$ wielu pokazach związanych $\mathrm{z}$ pracą maszyn górniczych, poznać dawne życie w zakładach przemysłowych i kulturę industrialną (www.industriada.pl).

Z przytoczonych działań na poziomie całego SZT można wywnioskować, że zarządca poprzez różnorodność promocyjnych, aktywizujących wydarzeń starał się zachęcić turystów do pogłębiania wiedzy o zgromadzonych obiektach na szlaku oraz odkrywać nowe, mniej poznane miejsca, do których w rzeczywistości turyści rzadko zaglądają. Ponadto ważnym aspektem jest utrwalanie w świadomości turystów przy użyciu narzędzi online walorów kulturowych szlaku oraz korzyści wynikających z odwiedzin, by po zniesieniu restrykcji fizycznie odwiedzili Szlak Zabytków Techniki.

\section{Metodyka badań}

Kwerenda piśmiennictwa związana ze zdefiniowaniem produktu turystycznego - szlaku - i produktu sieciowego pomogła $\mathrm{w}$ zrozumieniu istoty funkcjonowania Szlaku Zabytków Techniki i zarządzania nim. Przedstawienie wpływu pandemii na województwo śląskie pokazuje, $z$ jak trudnym zadaniem, polegającym na zwalczaniu niekorzystnego wizerunku oraz zachęcaniu do odwiedzin szlaku, przyszło zmagać się zarządcom poszczególnych obiektów.

Zakres podmiotowy stanowią celowo wybrane obiekty, których ekspozycję turysta zwiedza wewnątrz, reprezentujące 3 kategorie: browary, kopalnia, muzea. Przedstawione grupy oddają charakter grup obiektów ze szlaku. Autorzy dokonali 
takiej kategoryzacji ze względu na różnorodność obiektów SZT oraz na ich sytuację $\mathrm{w}$ czasie pandemii. $\mathrm{Z}$ powodu wprowadzonych obostrzeń obiekty z ekspozycją urządzoną wewnątrz, zostały nimi najbardziej dotknięte. Funkcjonowanie tych obiektów było uzależnione od rozwoju pandemii.

Browary analizowane w pracy to Tyskie Browary Książęce, Browar Obywatelski w Tychach oraz Browar Zamkowy w Cieszynie. Są to podmioty prywatne. Tyskie Browary Książęce to Gwiazda Techniki. Z uwagi na specyfikę miejsca aktywność w mediach społecznościowych mogła być ograniczona, ponieważ osoby poniżej 18 roku życia nie mogą spożywać piwa, co przekłada się na mniejszą grupę odbiorców.

Kopalnie poddane analizie to Kopalnia Guido w Zabrzu, Kopalnia Srebra w Tarnowskich Górach i Sztygarka w Dąbrowie Górniczej. Ekspozycje zwiedzane w tych kopalniach znajdują się pod ziemią oraz prezentują, jak kiedyś wyglądała praca górnika. Kopalnia Guido w Zabrzu oraz Kopalnia Srebra w Tarnowskich Górach znajdują się na liście Gwiazd Techniki. Te 3 kopalnie należą do sektora publicznego.

Muzea wybrane przez autorów to Muzeum Śląskie, Stara Fabryka w Bielsku, Muzeum Hutnictwa Cynku w Katowicach „Walcownia” oraz Muzeum Chleba, Szkoły i Ciekawostek w Radzionkowie. Muzeum Śląskie i Stara Fabryka w Bielsku to podmioty publiczne, natomiast pozostałe należą do sektora prywatnego. W obiektach tych pokazano na ekspozycjach dawne życie na śląsku, sztukę i kulturę industrialną oraz pracę w fabryce.

Zakres przedmiotowy badań dotyczy profili (publikowanych postów) tych obiektów w mediach społecznościowych, konkretnie na Facebooku. Facebook umożliwia wzajemną komunikację, dzielenie się treścią z innymi użytkownikami, obserwowanie aktywności innych użytkowników oraz interakcje. Do grupy postów zaklasyfikowano wszystko to, co można zobaczyć na oficjalnym profilu na Facebooku obiektu. Posty analizowano pod kątem zawartości, przyjęto następujący klucz kategoryzacyjny:

1. Informacje na temat ekspozycji - informacje o posiadanej ekspozycji, prezentowanie jej walorów kulturowych, zdjęć itp.

2. Informacje organizacyjne - dotyczące zamknięcia obiektu, wymogów sanitarnych itp.

3. Informacje odnoszące się do promocji wytwarzanych produktów - prezentacje produktu na sprzedaż, opis produktu i jego oferty oraz ceny.

4. Organizowanie różnego rodzaju działalności online, np. webinariów.

5. Udostępnianie aktywności online innych podmiotów o tematyce zbliżonej do tej, którą zajmuje się obiekt.

6. Udostępnianie aktywności ze strony/profilu Szlaku Zabytków Techniki.

7. Społeczna odpowiedzialność przedsiębiorstw - promocja akcji na rzecz pomocy innym, np. szycie maseczek.

8. Inne.

Zakres czasowy badań obejmuje daty: 11 marca-4 maja 2020 r. oraz 7 listopada-15 grudnia 2020 r. Są to daty związane z pełnym zamknięciem obiektów, które obsługują m.in. ruch turystyczny. Daty kończące największe obostrzenia 
umożliwiały ponowne funkcjonowanie placówek turystycznych, jednak to, czy dana placówka wznowi tradycyjne funkcjonowanie i kiedy to nastąpi, było zależne od samych zarządców.

\section{Wyniki badań}

Autorzy przeprowadzili analizy postów publikowanych na Facebooku w dwóch okresach zamknięcia. Poniżej zamieszczono trzy tabele przedstawiające dokonaną analizę. Numery kolumn odpowiadają opisowi klucza kategoryzacyjnego w metodyce badań.

Pierwszą analizowaną grupę stanowiły browary. Wyniki analiz zestawiono w tabeli 1.

Tabela 1. Analiza aktywności na Facebooku obiektów browarnianych

\begin{tabular}{lccccccccc}
\hline \multicolumn{1}{c}{ Obiekt } & Okres & 1. & 2. & 3. & 4. & 5. & 6. & 7. & 8. \\
\hline Browar Obywatelski Tychy & $11.03-4.05$ & 0 & 5 & 9 & 1 & 0 & 0 & 1 & 0 \\
& $7.11-15.12$ & 0 & 0 & 1 & 0 & 1 & 0 & 0 & 0 \\
Browar Zamkowy Cieszyn & $11.03-4.05$ & 0 & 3 & 8 & 2 & 0 & 0 & 3 & 2 \\
& $7.11-15.12$ & 0 & 2 & 7 & 1 & 2 & 0 & 0 & 0 \\
Muzeum Tyskie Browary & $11.03-4.05$ & 2 & 1 & 1 & 0 & 0 & 0 & 0 & 0 \\
Książęce & $7.11-15.12$ & 1 & 0 & 0 & 0 & 0 & 0 & 0 & 0 \\
\hline
\end{tabular}

Źródło: opracowanie własne na podstawie stron internetowych obiektów na Facebooku.

W kategorii browary można wywnioskować, że aktywność opiera się głównie na promocji produktów i usług oferowanych przez nie oraz informacji dotyczącej działalności obiektu. Wyraźnie można zauważyć, że aktywność w pierwszym okresie zamknięcia jest większa niż w drugim. W Browarze Obywatelskim Tychy aktywność w pierwszym okresie zamknięcia na profilu przejawia się głównie poprzez promocję oferty (usługi i produkty oferowane na miejscu lub na wynos, przez stronę internetowa) oraz informacje odnoszące się do działalności obiektu. W drugim okresie aktywność prawie zanikła. Browar Zamkowy Cieszyn w obu okresach aktywnie promował swoje wyroby. W pierwszym udostępniał posty z przekazania szpitalom zgrzewek napoi, w drugim uprawiał aktywność online. Umożliwiał też wirtualne zwiedzanie browaru oraz urządzał we współpracy webinaria i promocje swoich produktów. Jakość postów jest wysoka i odznacza się dużą estetyką, w szczególności materiały w postach promujących sprzedawane napoje. W Muzeum Tyskie Browary Książęce analiza wykazywała w obu okresach minimalną aktywność, głównie informacyjną, dotyczącą ekspozycji, oraz promocyjną.

Drugą analizowaną grupę stanowiły kopalnie. Wyniki analiz przedstawiono w tabeli 2.

Obiekty wykazywały się różnorodną aktywnością, jednak w okresie od 7 listopada aktywność spadła. Charakterystyczne jest, że obiekty przejawiały aktywność 
Tabela 2. Analiza aktywności na Facebooku obiektów kopalnianych

\begin{tabular}{lcrrrrrrrr}
\hline \multicolumn{1}{c}{ Obiekt } & Okres & 1. & 2. & 3. & 4. & 5. & 6. & 7. & 8. \\
\hline Kopalnia Guido & $11.03-4.05$ & 0 & 5 & 1 & 14 & 0 & 0 & 10 & 2 \\
& $7.11-15.12$ & 3 & 0 & 6 & 16 & 7 & 1 & 0 & 2 \\
Zabytkowa Kopalnia Srebra & $11.03-4.05$ & 4 & 3 & 7 & 13 & 1 & 0 & 1 & 4 \\
Tarnowskie Góry & $7.11-15.12$ & 2 & 1 & 3 & 1 & 1 & 0 & 0 & 0 \\
Muzeum Sztygarka & $11.03-4.05$ & 6 & 3 & 2 & 13 & 41 & 0 & 0 & 52 \\
& $7.11-15.12$ & 46 & 6 & 11 & 20 & 28 & 0 & 1 & 23 \\
\hline
\end{tabular}

Źródło: opracowanie własne na podstawie stron internetowych obiektów na Facebooku.

online, poprzez webinaria, reprodukcję filmów, zabaw interaktywnych, quizów i zadań mających na celu zaangażowanie obserwujących. Kopalnia Guido cechowała się podobną aktywnością zarówno w pierwszym, jak i drugim okresie zamknięcia. Zorganizowała serię filmów tematycznych. W pierwszym okresie ponadto upowszechniała posty dotyczące szycia maseczek przez pracowników muzeum. Jako jedyny obiekt udostępniała aktywności profilu Szlaku Zabytków Techniki. Kopalnia Srebra Tarnowskie Góry wykazywała głównie aktywność online, taką jak webinaria, konkursy itp. W drugim okresie widoczna była zmniejszona aktywność online. Profil Muzeum Sztygarka był prowadzony bardzo aktywnie, lecz niespójnie - treść stanowią posty o różnorodnej tematyce, często niezwiązanej z działalnością muzeum, stąd duża liczba postów w kategorii inne. W obu badanych okresach występuje różnica w jakości treści. Na uwagę zasługuje duża liczba postów dotycząca ekspozycji muzealnej dobrana do okoliczności czasowych oraz produkcja filmów edukacyjnych.

Trzecią analizowaną grupą były muzea. Wyniki analiz przedstawiono w tabeli 3.

Tabela 3. Analiza aktywności na Facebooku obiektów muzealnych

\begin{tabular}{lcrrrrrrrr}
\hline \multicolumn{1}{c}{ Obiekt } & Okres & 1. & 2. & 3. & 4. & 5. & 6. & 7. & 8. \\
\hline Muzeum Śląskie & $11.03-4.05$ & 31 & 1 & 3 & 8 & 1 & 0 & 1 & 1 \\
& $7.11-15.12$ & 29 & 1 & 9 & 34 & 6 & 0 & 0 & 3 \\
Stara Fabryka Bielsko-Biała & $11.03-4.05$ & 1 & 0 & 0 & 0 & 0 & 0 & 0 & 0 \\
& $7.11-15.12$ & 2 & 0 & 1 & 0 & 0 & 0 & 0 & 0 \\
Walcownia & $11.03-4.05$ & 34 & 1 & 2 & 9 & 4 & 0 & 2 & 8 \\
Muzeum Chleba & $7.11-15.12$ & 14 & 2 & 3 & 6 & 3 & 1 & 0 & 3 \\
W Radzionkowie & $11.03-4.05$ & 7 & 2 & 0 & 1 & 1 & 0 & 1 & 3 \\
& $7.11-15.12$ & 0 & 0 & 0 & 0 & 1 & 0 & 0 & 1 \\
\hline
\end{tabular}

Źródło: opracowanie własne na podstawie stron internetowych obiektów na Facebooku.

Obiekty muzealne w badanych okresach największą aktywność skupiły na prezentowaniu ekspozycji, np. zdjęć, obrazów, ciekawostek o maszynach przemysłowych, oraz na przeprowadzaniu różnego rodzaju działań online. Pierwszy okres zamknięcia badanych obiektów został wykorzystany głównie na prezentację 
zbiorów muzealnych, natomiast $\mathrm{w}$ drugim okresie można zaobserwować ich spadek. Obiekty te chętnie udostępniają wydarzenia online innych podmiotów oraz promują własne wyroby i gadżety ze swoich sklepów. Największą aktywność zaobserwowano w Muzeum Śląskim. Potwierdza to rangę obiektu, który świadczy kompleksową ofertę dostosowaną do każdej grupy odbiorców. Najmniejszą aktywność odnotowano w Starej Fabryce Bielsko-Biała. Muzeum Walcownia publikowało najwięcej postów związanych z ekspozycją w pierwszym okresie zamknięcia. Natomiast Muzeum Chleba w Radzionkowie tylko w pierwszym badanym okresie wykazywało aktywność.

\section{Zakończenie}

Z aktywności podmiotów na portalu społecznościowym Facebook można wyciągnąć kilka wniosków.

Po pierwsze, aktywność obiektów była wyraźnie większa w pierwszym okresie lockdownu i była ona próbą ratowania działalności zagrożonej nową, dynamicznie rozwijającą się sytuacją. W drugim, jesiennym okresię, widoczny jest spadek lub prawie całkowity zanik aktywności. Może on wynikać z przyzwyczajenia się do sytuacji, większych ograniczeń państwowych bądź większego doświadczenia w zarządzaniu obiektami w niesprzyjających warunkach. Obiekty w czasie pierwszego lockdownu zdobyły pewne doświadczenie, które pomogło im podjąć decyzję co do dalszej aktywności na Facebooku, przez co jedne ograniczyły, nawet znacząco, udostępnianie treści, a inne je rozwinęły. Największą aktywność można zauważyć w obiektach z sektora publicznego.

Kolejny wniosek nasuwający się na podstawie analizy obiektów ze szlaku jest taki, że jakość postów w miarę rozwoju kryzysu nie zmieniła się znacząco. Wiele obiektów, jak w przypadku Muzeum Sztygarka w Dąbrowie Górniczej, nie prowadzi polityki promocyjnej w social mediach, przez co treści udostępniane na portalach są słabej jakości, nie wyróżniają się w szumie medialnym i nie wywołują przez to pożądanych efektów. Analizowane obiekty udostępniały posty o różnorodnej tematyce, często posiłkując się aktywnością innych podmiotów, co świadczy o pewnym rozeznaniu co do możliwości social mediów oraz chęci współpracy poprzez zgrupowanie w sieci podmiotów na SZT.

Trudno jest wskazać, która $z$ trzech badanych kategorii obiektów poradziła sobie najlepiej. $Z$ tego wynika, że rodzaj obiektu nie miał większego znaczenia w przypadku aktywności na Facebooku. Przedstawione wnioski w pracy warto byłoby skonfrontować $z$ wypowiedziami przedstawicieli obiektów, co może stanowić dalszy kierunek badań.

Powyższa analiza pokazuje jedynie efekt wprowadzenia obostrzeń spowodowanych pandemią COVID-19 na aktywność wybranych obiektów ze Szlaku Zabytków Techniki w mediach społecznościowych. W czasie opracowania tego rozdziału epidemia koronawirusa i związane $z$ tym obostrzenia społeczno-gospodarcze nadal trwały, przez co analiza jest ograniczona i prowadzona „na gorąco”. Efekty aktywności badanych obiektów na Facebooku będą widoczne prawdopodobnie za 
kilka miesięcy, kiedy w okresie letnim przewidywane jest powolne odchodzenie od ograniczeń i przywracanie porządku gospodarczego po okresie pandemicznym. Wtedy będzie można ocenić wpływ aktywności na Facebooku na popularność obiektu i, co za tym idzie, liczbę odwiedzających oraz wpływy z biletów. Może to stanowić przedmiot dalszych badań. Jednakże, aby dobrze wykorzystać swoje możliwości, zarządcy obiektów powinni cały czas być aktywni w mediach społecznościowych oraz organizować różnego rodzaju inicjatywy online.

\section{Literatura}

Balińska A. (2017). Sieciowe produkty turystyczne jako przykład przedsiębiorczości na obszarach wiejskich. Turystyka i Rozwój Regionalny, 8: 5-14.

Browar Obywatelski Tychy (https://pl-pl.facebook.com/BrowarObywatelskiTychy/; dostęp: 12.12.2020).

Browar Zamkowy Cieszyn (https://www.facebook.com/BrowarCieszyn/; dostęp: 12.12.2020).

Industriada (http://industriada.pl/; dostęp: 10.12.2020).

Kasperska E. (2013). Promocja instytucji kultury na przykładzie muzeów etnograficznych na wolnym powietrzu. Zeszyty Naukowe Uniwersytetu Szczecińskiego, 30: 59-74.

Kłusek B. (2020). Funkcjonowanie Muzeum Niepodległości online w okresie lockdownu instytucji kultury. Niepodległość i Pamięć, 3(71): 131-150.

Kopalnia Guido (https://pl-pl.facebook.com/kopalniaguido; dostęp: 11.12.2020).

Kopalnia Srebra Tarnowskie Góry (https://pl-pl.facebook.com/ZabytkowaKopalniaSrebra; dostęp: 12.12.2020).

Maciąg J. (2015). Jakość sieciowego produktu turystycznego - definiowanie, wymiary i cechy jakości. Studia Ekonomiczne, Zeszyty Naukowe Uniwersytetu Ekonomicznego w Katowicach, 215: 40-56.

Muzeum Chleba w Radzionkowie (https://www.facebook.com/MuzeumChleba; dostęp: 10.12.2020).

Muzeum Sztygarka (https://pl-pl.facebook.com/pages/category/History-Museum/Muzeum-Miejskie-Sztygarka-Mms-298462153698416; dostęp: 14.12.2020).

Muzeum Śląskie (https://www.facebook.com/muzeumslaskie; dostęp: 12.12.2020).

Muzeum Tyskie Browary Książęce (https://www.facebook.com/browarytyskie; dostęp: 11.12.2020).

Polska Organizacja Turystyczna (www.pot.gov.pl; dostęp: 5.12.2020).

Portal ABCZdrowie (www.portal.abczdrowie.pl; dostęp: 10.12.2020).

Stara Fabryka Bielsko-Biała (https://www.facebook.com/pages/Stara\%20Fabryka\%20 Bielsko-Biala/1642975679338452; dostęp: 15.12.2020).

Stasiak A. (2006). Produkt turystyczny - szlak. Turystyka i Hotelarstwo, 10: 9-40.

Walcownia (https://www.facebook.com/walcownia; dostęp: 14.12.2020).

Wiadomości Onet (https://wiadomosci.onet.pl/kraj/koronawirus-jak-rozwijala-sieepidemia-w-polsce-i-na-swiecie-kalendarium/xgt8wcd; dostęp: 10.12.2020).

Zabytki Techniki (https://www.zabytkitechniki.pl/news/1019153/rusza-kampania-wybieram-slaskie-slaskie-smaki; dostęp: 5.12.2020).

Zabytki Techniki (https://www.zabytkitechniki.pl/news/1019743/uwaga-mamy-dla-was-konkurs; dostęp: 5.12.2020). 
Zabytki Techniki (https://www.zabytkitechniki.pl/news/1020020/technika-to-was-zaskoczy; dostęp: 10.12.2020).

Zabytki Techniki (www.zabytkitechniki.pl; dostęp: 15.12.2020).

\section{Activity of selected objects of the industrial monuments trail in the social media during COVID-19 pandemic}

The main aim is to compare the activity of the Industrial Monuments Trail in the social media during the COVID-19 pandemic. The social media of selected objects from the Trail were analyzed, grouped according to 3 categories: brewery, mine and museum. The analysis showed that the objects cooperated with each other, carried out a lot of campaigns to promote their exhibitions. The research was based on a critical analysis of the literature on the subject and the case study - Industrial Monuments Route.

Translated by Patrycja Żychoń 